\title{
Secrecy and the bottom line
}

\section{Washington \& London}

EVEN as UK scientists criticized the US National Institutes of Health (NIH) for raising the spectre of commerce in trying to patent gene sequences, the UK genome project has been holding its sequences secret while it prepares to sell them to industry.

Over the past year, researchers working on the Human Genome Mapping Project of the UK Medical Research Council (MRC) have identified about 2,000 human genes, in the form of sequences of fragments of complementary DNA, or cDNA. But rather than publish these sequences or make them available to other scientists, project officials have kept them in closely guarded storage while they developed a database that would allow them to charge industry for access.

Because cDNA, which is the genetic material actually expressed in the body, represents functioning genes, rather than just genetic material that may or may not have a function, researchers consider cDNA sequences more marketable than simple DNA fragments.

The UK project is preparing to sell access to its genome databases at an initial cost of $£ 5,000$ per company per year, plus $£ 1,000$ for each additional user within the same company. Academic scientists who agreed to sign a non-commercialization agreement would get free access. More than 700 such academics are now using the existing DNA databases of the MRC, which do not yet include the cDNA libraries. No companies have yet been given access to the databases. Although project officials explain that they are simply applying standard MRC policy to "take opportunities for commercialization where they arise", this is believed to be the first time a government has decided to sell its portion of the international genome effort.

"It's well known that the [UK] government does not wish to fund research that is near to the market," says MRC project manager Tony Vickers. "If research has reached a stage of development where an application is round the corner, then industry pays." Vickers believes that cDNA sequences - even though their particular function is still unknown - are close enough to a possible product to justify charging industry for their use.

The UK attempt to sell their genome data "is a sty in the eye of international progress on the genome," says Charles Cantor, chief scientist for the US Department of Energy's Human Genome Project and vice president for the Americas for the Human Genome Organization (HUGO). HUGO plans to convene a meeting soon to discuss how to respond to the MRC plans. "It's against the spirit of what's being done in the United States," Cantor says. He suspects that criticism from international genome researchers will "force the UK to shift its position on this."

Before settling on the pay-for-access approach, MRC officials had also looked into the possibility of patenting cDNA sequences. But UK lawyers advised them that such patents were unlikely to be granted. Now that NIH has decided to take the patent leap, the MRC group may have been "caught with their knickers down", one NIH researcher says.

If so, this would not be the first time. Behind the MRC preoccupation with commercializing its research is the still-painful memory of the technique MRC scientists developed - and neglected to patent - for producing monoclonal antibodies.

Until Craig Venter of the NIH filed a patent application for 337 cDNA sequences in June (see Nature 353, 485; 10 October 1991), the MRC group had intended to open its cDNA library for business this month. Now that NIH has taken the patent route, the MRC group is waiting for a ruling from the US patent office before opening its database in any form. If the patent office finds cDNA patentable, the MRC group expects to seek patents as well. Until that question is answered, however, "all deals are off," says Vickers. "I'd get crucified if I made the sequences publicly available now.'

Like many other genome researchers, Vickers has harshly criticized Venter and NIH for attempting to patent the cDNA sequences, something he has described as "seriously prejudicial to the whole thrust of the international Human Genome Project" (see Nature 353, 785; 31 October 1991). But NIH scientists are now crying foul: the MRC's plan to keep the data in a closely held database, they argue, runs counter to international agreements to share and exchange genome data.

The difference between the two groups, Venter says, is that his laboratory published (and sought patents on) its data as soon as it was ready; the MRC project has not published its data at all. Venter also says that he has been seeking an exchange of data between the two laboratories for nearly a year, with no success. "We offered on numerous occasions to exchange a complete data set prior to publication and even offered to hold up our submission [to Science] so we could publish jointly," he says. "But we were told that the data were to be held secret and would be unavailable for exchange."

Vickers says that the MRC group was not ready to publish when Venter first broached the issue - its sequencing system had been running for just one month.
The MRC group also wanted to get the ground rules for data exchange sorted out internationally before making a start on exchange. Until the United States and other countries had come up with some overall data policy, he says, the MRC group was not prepared to start wholesale transfers of its cDNA sequence library.

But it now appears that the MRC may never publish its cDNA sequences at all. "There is no point in a second publication covering the same ground," Vickers explains. Critics suggest that there may be a commercial reason as well: companies would be unlikely to buy the data if it were publicly available. Whatever the resolution in this case, the end result is clear: now that the issue of commercializing the human genome has become an international controversy, data appear to be the hostage of choice.

Christopher Anderson \& Peter Aldhous

\section{DISASTER PREVENTION}

\section{Quake raises doubts about Indian dam}

\section{New Delhi}

AN earthquake that shook northern India on 20 October has added fresh fuel to the controversy over the safety of the $\$ 1,300$. billion, 265-metre-high dam under construction in the Himalayas. Tehri Dam, being built with a $\$ 700$-million loan and technical help from the Soviet Union, is $100 \mathrm{~km}$ from Almora, epicentre of the recent earthquake that killed 1,500 people and shattered 6,000 homes.

The dam suffered no damage from the earthquake, which registered 6.1 on the Richter scale. But environmentalists, led by the Indian National Trust for Art and Cultural Heritage (INTACH) want the work to be stopped to avert a major disas. ter they say will occur in the event of a bigger earthquake in the fragile mountains. INTACH has filed a petition in the Supreme Court.

Soviet engineers have designed the dam to withstand an earthquake of magnitude 7.2 and a ground acceleration of $0.25 \mathrm{~g}$. But Vinod Gaur, an Indian seismologist, has warned that an earthquake of magnitude 8 or above is likely because of the location in a 'seismic gap' where strain has been accumulating for centuries. He said that such an earthquake may be on the way.

Despite criticisms, the government has shown no signs of giving in to the environmentalist lobby. Prime Minister P.V. Narasimha Rao, returning from a tour of earthquake-ravaged areas, acknowledged that the earthquake has raised some questions about the dam that must be answered. But the ministries responsible for the project say that work on the project will continue without any design changes. K.S. Jayaraman 